\title{
Growth factor/growth factor receptor loops in autocrine growth regulation of human prostate cancer DU145 cells
}

\author{
Janusz Ligęza ${ }^{\bowtie}$, Joanna Ligęza and Andrzej Klein \\ Department of General Biochemistry, Faculty of Biochemistry, Biophysics and Biotechnology, Jagiellonian University, Kraków, Poland
}

Autocrine growth factors produced by epithelial cells mediate the development and proliferation of neoplastic human prostate tissue. Various approaches have been used to down-regulate neoplastic growth of prostate cancer using natural flavonoids, soluble receptors, pseudo-ligands, monoclonal antibodies and tyrosine kinase inhibitors (tyrphostins). Selected growth factor/growth factor receptor loops (mainly TGFa/EGFR and IGFs/IGFIR) have been proposed as regulators of prostate cancer cell growth. We have previously determined that blockade of IGFIR or VEGF2R signaling pathways by tyrphostin AG1024 and SU1498 inhibits autocrine growth and viability of DU145 cells in vitro. Recently, we compared the activity of AG1024 and SU1498 with the inhibiting effect of tyrphostin A23 (a selective inhibitor of EGFR). The results described in this paper confirm that DU145 cells do not produce IGFI or EGF. In contrast, DU145 cells produce a great amount of VEGF, much more than TGFa (about 60 -fold), and VEGF may be the real autocrine growth factor of the investigated cells. The results indicate that the growth of DU145 may be regulated by at least three autocrine loops: TGFa/EGFR, IGFII/IGFIR and VEGF/VEGFR2. Neither AG1024 nor SU1498 affected the production of TGFa substantially, which excludes the possibility that IGFRs or VEGFR2 inhibitors arrest the growth of these cells by inhibition of synthesis and/ or secretion of TGFa. The obtained data indicate that all tree investigated tyrphostins (AG1024, SU1498 and A23) inhibit signal transmission by Akt (PKB), ERK(1/2), Src and STAT in a similar manner. A comparison of the effects of the investigated tyrphostins indicates that TGFa, IGFII and VEGF stimulate cell growth by affecting the same signaling pathway. The hypothesis was confirmed by the effect of the investigated tyrphostins on activation of EGFR. All these inhibitors decreased phosphorylation of EGFR to the same extent, and after the same time of incubation with cell culture. These results strongly suggest that stimulation of EGFR kinase is the main step in the initiation of mitogen signaling in DU145 cells, regardless of the type of ligand (TGFa, IGFs or VEGF) and their specific receptors.

Keywords: tyrphostins, DU145 cells, receptor cross-talk, autocrine growth regulation

Received: 27 March, 2011; revised: 01 July, 2011; accepted: 10 August, 2011; available on-line: 29 August, 2011

\section{INTRODUCTION}

An important event in the development of the neoplastic phenotype is the induction of genes encoding growth factors and their receptor (Sporn \& Roberts,
1985; Goustin et al., 1986). The autocrine growth factormediated pathways are engaged in proliferation of human prostate cancer cells, including the DU145 cell line (Marker et al., 2003; Bellezza et al., 2006). Understanding the role of different growth factors in the control of autocrine growth may help to clarify the mechanism of prostate cancer progression.

The growth of human prostate cancer cells is probably dependent on several growth factors. Members of the EGF, IGF, PDGF, VEGF and FGF families and neurotrophins have been postulated as stimulators of prostate cell growth (Ferrer et al., 1999; Ozen et al., 2001; Montano \& Djamgoz, 2004; Bellezza et al., 2006; Gennigens et al., 2006). Selected growth factor/growth factor receptor loops such as EGF/EGFRs, IGFs/IGFRs and FGFs/FGFRs are probably engaged in the autocrine growth regulation of prostate cancer cell lines (Ozen et al., 2001; Bellezza et al., 2006; Gennigens et al., 2006). An increased production of transforming growth factor $\alpha(T G F \alpha)$, ligand from EGF family, has been found in several prostate cell lines, including DU145 and synthetic inhibitors of EGFR have been shown to decrease the proliferation of different prostate cell lines (Vicentini et al., 2003; Bonaccorsi et al., 2004; Sgambato et al., 2004). On the other hand, acquired resistance to inhibitors of EGFR has been reported clinically (Jimeno \& Hidalgo, 2005) and suggested to be associated with increased signaling through the IGFI receptor (Jones et al., 2004). A high level of IGFs and VEGF has also been observed in patients with prostate cancer (Ferrer et al., 1999; Gennigens et al., 2006) suggesting their participation in autocrine growth regulation of the investigated cells. It has been proposed, that IGFs affect the growth of prostate cells via the EGF receptor and VEGF is a mediator of their motility and an angiogenic factor (Jackson et al., 2002). In contrast to EGF, IGF and VEGF, the production of NGF is progressively lost in prostate cancer development (Montano \& Djamgoz, 2004) and exogenous NGF inhibits the growth of DU145 cells (Sigala et al., 2008).

The mechanism of autocrine growth regulation of prostate cells is far from being explained. Why does one type of cancer cells produce increased levels of several growth factors and do they activate the same or different signaling pathways?. Investigation of the molecular mechanisms of interaction between different autocrine

e-mail: janusz.ligeza@uj.edu.pl

Abbreviations: Akt (PKB), kinase Akt (protein kinase B); EGF, epidermal growth factor; ERK, extracellular signal-related kinase; FGF, fibroblast growth factor; IGF, insulin-like growth factor; NGF, nerve growth factor; PDGF, platelet-derived growth factor; $R$, receptor; STAT, signal transducers and activators of transcription; TGFa, transforming growth factor $a$; VEGF, vascular endothelial growth factor 
signal pathways may explain the mechanism of neoplastic growth and resistance of cancer cells to single inhibitors (cytostatics), often observed in anticancer therapy.

A useful tool for use in the investigation of autocrine cell growth regulation are inhibitors of tyrosine kinases (Bennasroune et al., 2004; Madhusudan \& Ganesan, 2004; Lacal, 2006), including small-molecular compounds known as tyrphostins (tyrosine kinase inhibitors) (Levitzki \& Gazit, 1995). Previous experiments indicated that tyrphostins: AG1024 and SU1498 inhibit autocrine growth of DU145 human prostate cancer cells in a dosedependent manner (Kisielewska et al., 2008). In this paper, we compare the mitogenic signal transmission initiated by different autocrine growth factor receptors of DU145 cells: EGFR, IGFIR and VEGFR2.

\section{MATERIALS AND METHODS}

Chemicals and reagents. Dulbecco's Modified Eagle's Medium/Nutrient F-12 Ham (DMEM/F12), Minimal Essential Medium (MEM), bovine serum albumin (BSA), transferrin, sodium selenite $\left(\mathrm{Na}_{2} \mathrm{SeO}_{3}\right)$, Hoechst 33258, propidium iodide, MT'T (thiazolyl blue tetrazolium bromide), dimethylsulfoxide (DMSO) and tyrosine kinase inhibitors: A23 (EGFR $\mathrm{IC}_{50}=35 \mu \mathrm{M}$ ), AG1024 $\left(\right.$ IGFIR $\left.\mathrm{IC}_{50}=0.4 \mu \mathrm{M}\right)$ and SU1498 (VEGFR2 $\mathrm{IC}_{50}=0.7$ $\mu \mathrm{M})$ were purchased from Sigma (St. Louis, MO, USA). Fetal bovine serum (FBS) was obtained from PAA Laboratories $\mathrm{GmbH}$ (Austria). RNeasy ${ }^{\circledR}$ Mini Kit was purchased from QIAGEN (Germany). RayBio® Human EGF (TGF $\alpha$, VEGF, IGFI) ELISA kits were bought from RayBiotech, Inc. (USA). Oligo GEArray ${ }^{\circledR}$ Human Cancer Pathway Finder ${ }^{\mathrm{TM}}$ and CASETM (Cellular Activation of Signaling ELISA) kits for EGFR, Akt, ERK1/2, Src and STAT3 were obtained from SuperArray Bioscience Corporation (USA). X-Ray film was obtained from Agfa (Belgium). Other reagents were provided by POCh (Gliwice, Poland).

Stock solutions of the tyrphostins were prepared by dissolving the compounds in DMSO to the final concentration of $10 \mathrm{mM}$ or $100 \mathrm{mM}$ in the case of A23 and storing the resultant solutions at $-20^{\circ} \mathrm{C}$. DMEM/ F12 (1:1) medium was used do dilute stock solutions to working concentrations $(1-10 \mu \mathrm{M})$.

Cell culture. DU145 (HTB-81) cells were obtained from the American Type Culture Collection (ATCC) and cultured in MEM in the presence of $10 \%$ FBS. The cells were passaged two times per week. The experiments were carried out in DMEM/F12 supplemented with BSA $(0.5 \mathrm{mg} / \mathrm{ml})$, transferrin $(5 \mu \mathrm{g} / \mathrm{ml})$ and $\mathrm{Na}_{2} \mathrm{SeO}_{3}$ (2 $\mathrm{ng} / \mathrm{ml})$.

Proliferation of the investigated cells was determined by the procedure described earlier (Kisielewska et al., 2008). The mean \pm S.E.M. of at least three experiments with ten replicates each was used. Statistical analysis was performed with the use of the Statistica 9 program.

Cell cycle analysis. To estimate the proportion of cells in various phases of the cell cycle, cellular DNA contents was measured by flow cytometry (FACS Scan from Beckton-Dickinson) as described earlier (Kisielewska et al., 2008). The resultant data were analyzed with FCS Express V3 with Multicycle plug-in.

Cellular activation of signalling ELISA (CASE). Cells $\left(1 \times 10^{4}\right)$ were seeded in 96-well plates and cultured in DMEM containing 10\% FBS for one day, followed with a period of serum-deprivation of $24 \mathrm{~h}$ (in DMEM/ $\mathrm{F} 12+)$, then cultured for 3 to $24 \mathrm{~h}$ in DMEM/F12+ supplemented with the investigated tyrphostins (at respective $\mathrm{IC}_{50}$ concentrations). Next the cells were fixed (4\% formaldehyde) and stained with, phospho-protein or pan-protein primary antibodies $\left(12 \mathrm{~h}\right.$ at $\left.4{ }^{\circ} \mathrm{C}\right)$. Subsequently, the cells were washed, stained with secondary antibody (60 $\mathrm{min}$ at room temperature), incubated with color developer (3-5 minutes at room temp.), and the plates were read at $450 \mathrm{~nm}$. Thereafter, the plates were washed thrice with PBS and then stained with crystal violet. The absorbance was measured using a Tecan (Spectra Fluor Plus) multiscan plate reader.

Readings were taken to assess the total number of cells per well. The results were calculated as the ratio of $450 \mathrm{~nm}$ absorbance (antibody signal) and $595 \mathrm{~nm}$ absorbance (cell number), and normalized to non-stimulated cells.

RNA isolation. Total RNA was isolated from DU145 cells (up to $6 \times 10^{6}$ cells) using RNeasy Mini Kit (Qiagen, Hilden, Germany), dissolved in $30 \mu \mathrm{l}$ of RNase-free water and stored at $-20^{\circ} \mathrm{C}$. The integrity of ribosomal RNA and DNA contamination was checked using denaturing formaldehyde gel electrophoresis $(1 \%)$ before proceeding with the microarray analysis. Protein and phenol contamination and concentration of total RNA was assessed by determining the ratio $A_{260 / 280}$ and $A_{260 / 230}$, respectively (NanoDrop).

Microarray analysis. Superarray ${ }^{\circledR}$ hybridization was performed on 128 sites ( 2 blanks, 4 negative reference spots, 2 biotinylated artificial sequences, 6 household gene spots, and 113 human genes related to drug metabolism) on cDNA gene microarrays (Oligo GEArray ${ }^{\circledR}$ Human Cancer Pathway Finder ${ }^{\mathrm{TM}}$ OHS-033, SuperArray ${ }^{\circledR}$ Bioscience Corporation; Frederick, MD, USA). Four arrays were used to determine the difference in mRNA expression between cells treated with the three different receptor tyrosine kinase inhibitors (A23 $80 \mu \mathrm{M}$ and SU1498 $10 \mu \mathrm{M}$ and AG1024 10 $\mu \mathrm{M})$ and untreated cells.

DU145 cells were investigated after $24 \mathrm{~h}$ of serum starvation followed by $30 \mathrm{~h}$ incubation with or without (control) the investigated compounds.

Work-up of the array was performed according to the manufacturer's protocol. Single-stranded cDNA was synthesized (from approx. $6 \mu \mathrm{g}$ of total RNA) and labeled with dUTP-biotin by using the TrueLabellingAMPTM 2.0 kit. The nylon membrane based DNA macroarray was hybridized overnight at $60^{\circ} \mathrm{C}$ with the biotinlabelled cDNA. The hybridized membrane was subjected to chemiluminesence detection with streptavidin-linked alkaline phosphatase and CDPstar substrate. The resulting signals were captured on X-ray film and analyzed with the TIGR Spotfinder 3.1.1 program (Saeed et al., 2003). The assessed luminescence intensities were elaborated with the use of MIDAS program. Lowess smoothing and standard deviation regularization were applied to raw data (Quackenbush, 2002; Pasanen et al., 2003; Saeed et al., 2003).

The differences in mRNA levels for the investigated genes, between the control cells and tyrphostins-treated cells were expressed as $\log _{2}(\mathrm{~T} / \mathrm{C})$; where $\mathrm{T}$ is luminescence intensity of a spot on an array hybridized with cDNA obtained from tyrphostin-treated cells, and C from untreated cells.

Quantitation of selected growth factors in cell culture medium. DU145 cells were seeded on 24-well plates, $8 \times 10^{4}$ cells per well in MEM, SP, NEAA and $10 \%$ FBS. After $24 \mathrm{~h}$, the cells were serum-starved for $24 \mathrm{~h}$ in DMEM/F12+. Afterwards, the medium was replaced by a fresh dose of DMEM/F12+ supplemented or not with A23 $(80 \mu \mathrm{M})$, AG1024 $(8 \mu \mathrm{M})$, SU1498 (8 
Table 1. Percentage of DU145 cells in different cell cycle phases after incubation with tyrphostins

AG1024, SU1498 and A23 were added at concentration equal their respective $\mathrm{IC}_{50}$ and $2 \times \mathrm{IC}_{50}$ in serum-free DMEM/F12+ for 30 and $48 \mathrm{~h}$.

\begin{tabular}{|c|c|c|c|c|c|c|}
\hline \multirow{2}{*}{$30 \mathrm{~h}$} & & \multicolumn{3}{|c|}{ Cycle phase } & \multirow{2}{*}{ Apoptosis } & \multirow{2}{*}{$\mathrm{G}_{1} / \mathrm{G}_{2}$} \\
\hline & & $\mathrm{G}_{1} \& \mathrm{G}_{0}$ & $\mathrm{~S}$ & $\mathrm{G}_{2} \& \mathrm{M}$ & & \\
\hline \multirow{7}{*}{$\begin{array}{l}\cong \\
\bar{U} \\
\stackrel{u}{0} \\
0 \\
0\end{array}$} & Control & 57.0 & 25.5 & 17.5 & - & 3.26 \\
\hline & AG1024 IC 50 & 71.4 & 15.8 & 12.8 & - & 5.58 \\
\hline & AG1024 $10 \mu \mathrm{M}$ & 68.9 & 18.6 & 12.5 & - & 5.52 \\
\hline & SU1498 IC 50 & 74.1 & 10.6 & 15.3 & - & 4.85 \\
\hline & SU1498 $10 \mu \mathrm{M}$ & 68.4 & 16.7 & 14.9 & - & 4.59 \\
\hline & $\mathrm{A} 23 \mathrm{IC}_{50}$ & 59.7 & 19.1 & 11.7 & 8.3 & 5.09 \\
\hline & A23 $80 \mu \mathrm{M}$ & 56.1 & 24.4 & 9.8 & 8.7 & 5.74 \\
\hline \multirow{2}{*}{$48 \mathrm{~h}$} & & \multicolumn{3}{|c|}{ Cycle phase } & & \\
\hline & & $\mathrm{G}_{1} \& \mathrm{G}_{0}$ & $\mathrm{~S}$ & $\mathrm{G}_{2} \& \mathrm{M}$ & Apoptosis & $\mathrm{G}_{1} / \mathrm{G}_{2}$ \\
\hline \multirow{7}{*}{$\begin{array}{l}\cong \\
\bar{\Xi} \\
\stackrel{4}{0} \\
0\end{array}$} & Control & 60.8 & 21.7 & 17.5 & - & 3.47 \\
\hline & AG1024 IC 50 & 72.6 & 14.6 & 12.8 & - & 5.68 \\
\hline & AG1024 $10 \mu \mathrm{M}$ & 70.8 & 16.7 & 12.5 & - & 5.67 \\
\hline & SU1498 IC 50 & 72.2 & 9.7 & 11.8 & 3.7 & 6.12 \\
\hline & SU1498 $10 \mu \mathrm{M}$ & 67.03 & 14.64 & 12.51 & 4.96 & 5.36 \\
\hline & $A 23 I_{50}$ & 52.8 & 22.5 & 10.8 & 13.0 & 4.89 \\
\hline & A23 $80 \mu \mathrm{M}$ & 46.1 & 22.4 & 7.8 & 22.8 & 5.88 \\
\hline
\end{tabular}

TGF $\propto$, VEGF and IGF-I ELISA Kits following manufacturer's instruction with minor modifications. At the same time, the number of DU145 cells was estimated in each well. Conditioned media from cell cultures and standard solutions were incubated on ELISA plates overnight at $4{ }^{\circ} \mathrm{C}$. Biotin-labeled secondary antibodies were applied for $3 \mathrm{~h}$ in room temp. HRP-Streptavidin was added to the plates for $45 \mathrm{~min}$. Finally, TMB One-Step Substrate Reagent was added to each well and incubated in the dark with gentle shaking for $30 \mathrm{~min}$.

Standard curve (exponential model) was fitted to obtained data and the concentration of the secreted growth factors in culture medium was calculated. The results were expressed as pg or ng of the investigated protein produced by $1 \times 10^{6}$ cells after $24 \mathrm{~h}$ of incubation. The effects of tyrosine kinases inhibitors were shown as the ratio of the amount of growth factors produced by the treated cells to the amount produced by the control cells.

\section{RESULTS}

The recently reported results on the cytostatic effects of AG1024 and SU1498 on autocrine growth of DU145 cells (Kisielewska et al., 2008) indicated similar inhibitory activities of the both investigated tyrpostins. The next step in our investigations was a comparison of cytostatic activity of AG1024 and SU1498 $\mu \mathrm{M})$, and the cells were incubated for additional $24 \mathrm{~h}$ or 48 h. Subsequently, samples of culture media were collected and analyzed for the presence of the investigated growth factors with the use of RayBio Human EGF,

with the effect of a selective inhibitor of epidermal growth factor receptor (EGFR) - tyrphostin A23. The anti-proliferative activity of the investigated tyrphostins was determined by two colorimetric methods (MTT and CV). The influence of the tyrphostins on autocrine growth of DU145 cells was characterized by average values estimated by both methods. Tyrphostins A23, AG1024 and SU1498 inhibited growth of DU145 cells by $50 \%$ at the concentration: $35 \mu \mathrm{M}, 3.2 \mu \mathrm{M}$ and $3.6 \mu \mathrm{M}$ respectively.

These results indicate that only EGFR-induced signaling is inhibited by the specific tyrphostin (A23) in the same concentration range as the inhibition of the enzymatic activity of the kinase receptor $\left(\mathrm{IC}_{50}=35 \mu \mathrm{M}\right)$ and receptor autophosphorylation $\left(\mathrm{IC}_{50}=40 \mu \mathrm{M}\right)$. Effective cell growth inhibition by the other two investigated tyrphostins required much higher concentration of the compounds than those needed to inhibit the enzymatic activity of IGFIR and VEGFR2. However, to observe an inhibitory effect of the tyrphostin AG1024 (the effect of SU1498 was not determined) on the autophosphorylation of specific receptor $\left(\mathrm{IC}_{50}=7 \mu \mathrm{M}\right)$ required a similar concentration range as for cell proliferation of DU145 cells. It should be noted that the growth inhibition of DU145 cells by all the investigated tyrphostins was reversible (not shown).
Figure 1. Concentration of growth factors in DU145 cell culture medium Mean by ELISA method for cell culture medium after $24 \mathrm{~h}(\mathrm{C}, \mathrm{D})$ or $24 \mathrm{~h}$ and $48 \mathrm{~h}$ (A, B) of incubation, compared to mean values of absorbance for dilution buffer and two standard samples with lowest concentrations of EGF (A) and IGF-I (B) or three standard samples for TGFa (C) and VEGF (D). Differences between samples was assessed by Mann-Withney U-test $\left({ }^{*} p<0.05,{ }^{* *} p<0.001\right.$, ns, not significant). 


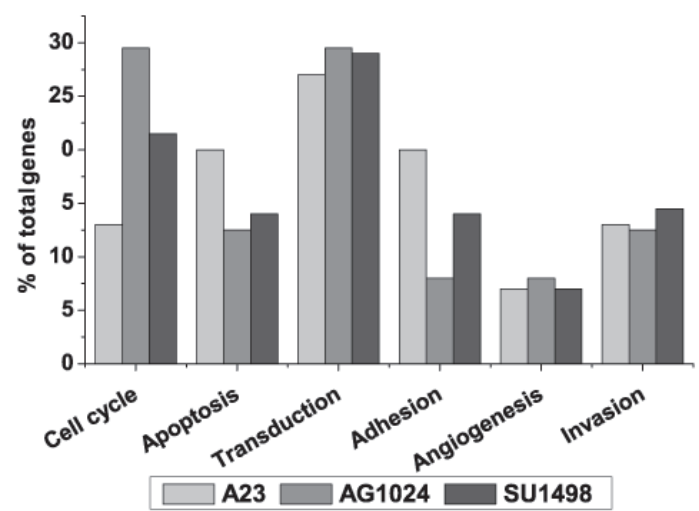

Figure 2. Influence of investigated tyrphostins on expression of genes engaged in different cellular processes

Proportion of up- or down-regulated to total analyzed genes involved in particular cell signalling pathways. DU145 cells were incubated for $30 \mathrm{~h}$ with AG1024, SU1498 and A23 added at concentration equal their $\mathrm{IC}_{50}$.

\section{Influence of tyrphostins AG1024, SU1498 and A23 on DU145 cell cycle}

The effect of tyrphostins AG1024 and SU1498 on the cell cycle was described earlier (Kisielewska et al., 2008). They influenced the cell cycle of DU145 in a similar manner. They increased the cell number in G1 and $S$ phases and decreased it in G2 phase in comparison with the control culture. AG1024 did not stimulate apoptosis, and the cytotoxic effect of SU1498 was very weak. In this paper, we compare the influence of AG1024 and SU1498 with the inhibitor of EGF receptor (A23) on the cell cycle of DU145 cells (tested in the same experiment). In contrast to tyrphostins AG1024 and SU1498, inhibition of EGF receptor by tyrphostin A23 was associated with a significantly increased proportion of apoptotic cells (Table 1).
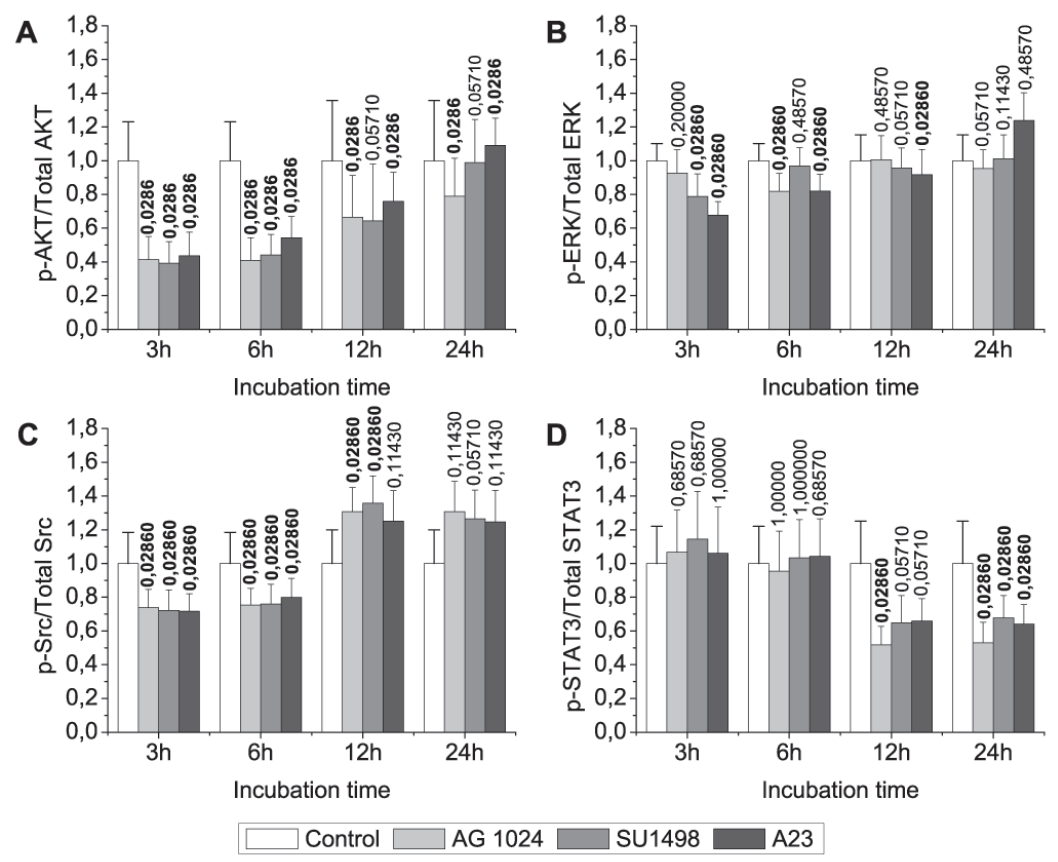

Figure 3. Effect of tyrphostins AG1024, SU1498 and A23 on phosphorylation of Akt (A), ERK (B), Src (C) and STAT (D) signaling proteins in DU145 cells

The investigated tyrphostins were added at concentration equal their $I_{50}$. Statistical significience $<0.05$ in bold.

\section{Synthesis of autocrine growth factors}

The effect of the investigated tyrphostins on growth and cell cycle of DU145 cells suggests one of the two possibilities: a) each of the inhibitors stimulates a separate signaling pathway or b) two or tree investigated inhibitors utilize a common pathway of mitogen signaling. The results shown in Fig. 1 indicate that DU145 cultured in DMEM/F12+ produce vascular endothelial growth factor (VEGF) and TGF $\alpha$ and confirm that the cells do not produce EGF and IGFI. Moreover, the amount of VEGF secreted to the culture medium calculated per $10^{6}$ cells, was about 60 times higher $(6.35 \pm 1.05 \mathrm{ng} / 24 \mathrm{~h})$ than the amount of TGF $\alpha(118.4 \pm 3.3 \mathrm{pg} / 24 \mathrm{~h})$. The prostate cancer cell line DU145 did not secrete a detectable amount of EGF or IGF-I, even after $48 \mathrm{~h}$ of incubation.

\section{Comparison of the effect of tyrphostins AG1024, SU1498 and A23 on gene expression and phosphorylation of selected signaling proteins}

To compare the signaling pathways of IGFIR, VEGFR2 and EGFR, we tested the effect of the investigated inhibitors on the expression of selected genes and on phosphorylation of some proteins engaged in mitogen stimulated signaling pathways.

The effect of the investigated tyrphostins on gene expression was assessed by cDNA microarray analysis, using Oligo GEArray Human Cancer Pathway Finder ${ }^{\mathrm{TM}}$ OHS-033. Four arrays were used to determine differences in mRNA expression between DU145 cells treated with A23, SU1498, and AG1024 (at the concentration equal to $\left.2 \times \mathrm{IC}_{50}\right)$ and untreated cells after $24 \mathrm{~h}$ serum starvation followed by $30 \mathrm{~h}$ incubation with or without (control) the investigated compounds. The effect of the inhibitors on the expression of selected genes related to six different signaling pathways is shown in Fig. 2. Differences (mainly between AG1024 and A23) were observed in the response of genes engaged in regulation of the cell cycle and cell adhesion. The former could have resulted, at least partly, from the ability of the investigated tyrphostins to stimulate apoptosis. Only A23 (at the concentration equal to its $\mathrm{IC}_{50}$ ) does effectively stimulate this process $(8.3 \%$ of apoptotic cells) after 30 $\mathrm{h}$ of incubation. The different effects on expression of genes engaged in cell adhesion may be characteristic for individual signaling pathways affected by these tyrphostins. In the remaining cellular processes, the differences in the levels of gene expression in response to individual inhibitors were much smaller.

Stimulation of EGFR receptor may trigger numerous intracellular signaling pathways involved in such processes as: survival (Akt/PKB), cell growth (ERK1/2; Src) and transcription (STAT). The activity of these proteins is regulated by phosphorylation/dephosphorylation. A comparison of the effects of the inhibitors of the EGFR, IGFIR and VEGFR2 tyrosine kinases on phosphorylation of the investigated proteins is shown in Fig. 3. The obtained results indicate a similar- 


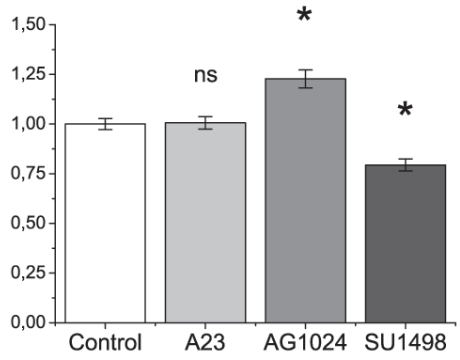

Figure 4. Effects of AG1024, SU1498 and A23 on synthesis and secretion by DU145 cells

Concentration of TGFa was assessed by ELISA after $30 \mathrm{~h}$ of incubation of DU145 cells in DMEM/F12+ supplemented or not with investigated tyrphostins. *Statistical significant $p<0.05$.

ity in growth factor-stimulated pathway signaling, probably with participation of the same signaling proteins. Therefore, we checked the influence of the investigated tyrphostins on phosphorylation of proteins involved in mitogen signaling pathway.

The time course of the changes in protein phosphorylation, as well as the level of inhibition for all three inhibitors was very similar. The phosphorylation of Akt was decreased to about $50 \%$ of the control value after $3 \mathrm{~h}$ of incubation, regardless of the kind of the investigated tyrphostin. It returned to the control level after $24 \mathrm{~h}$ of treatment with these tyrphostins. Similarly, phosphorylation of Src decreased to about $70 \%$ of the control level after the first $3 \mathrm{~h}$ of incubation with the investigated tyrphostins and returned to the control value after the subsequent $9 \mathrm{~h}$. Also the kinetics of the inhibition of STAT3 phosphorylation did not differ between the investigated compounds. A comparison of the effect of A23, AG1024 and SU1498 on ERK phosphorylation was difficult to interpret because of the small effect of the inhibitors. However, some differences in the inhibition activity of the investigated tyrphostins after the first $3 \mathrm{~h}$ and $6 \mathrm{~h}$ of incubation were observed.

\section{Effect of tyrphostins AG1024, SU1498 and A23 on TGFa production by DU145 cells}

One of the possible indirect actions of IGFs and VEGF on autocrine growth stimulation of DU145 cells was their effect on TGF $\alpha$ production. Therefore, we determined the effect of AG1024 and SU1498 (in comparison with A23) on the level of TGFa in the culture medium of the investigated cells. As shown in Fig. 4, DU145 cells incubated with tyrphostin A23 produced the same amount of $\mathrm{TGF} \alpha$ as untreated cells. AG1024, a selective inhibitor of IGFIR tyrosine kinase, increased the concentration of the secreted TGF $\alpha$ in the conditioned medium by about $24 \%$. In contrast, treatment with SU1498 resulted in lowering of the production of this EGFR ligand to $74 \%$ of the control value.

\section{Effect of tyrphostins AG1024, SU1498 and A23 on activation of EGFR}

Activation of receptor tyrosine kinases is due to their autophosphorylation, stimulated by specific ligand binding with the extracellular part of the receptor. The effect of tyrphostins AG1024, SU1498 and A23 on phosphorylation of EGFR in DU145 cells (Fig. 5) was surprising.

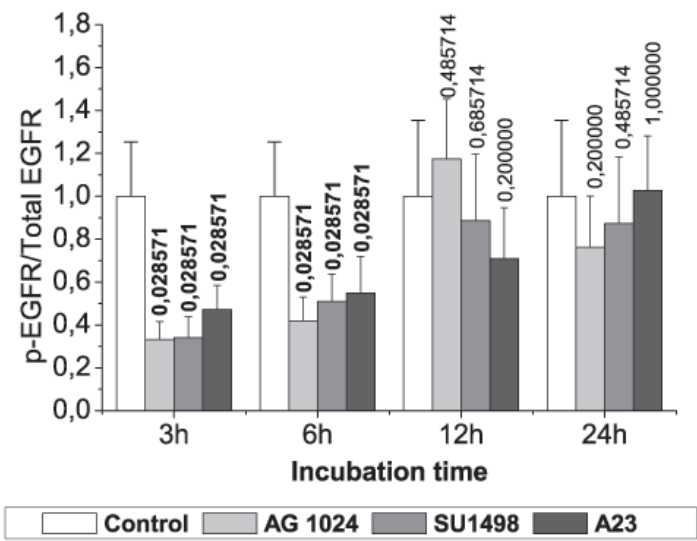

Figure 5. Influence of tyrphostins AG1024, SU1498 and A23 on EGFR phosphorylation

DU145 cells were incubated with investigated compounds (added at concentration equal $\mathrm{IC}_{50}$ ) for $3,6,12$ and $24 \mathrm{~h}$ in serum-free medium (DMEM/F12+). Statistical significance $<0.05$ in bold.

All the investigated inhibitors, used in respective $\mathrm{IC}_{50}$ concentrations, decreased the phosphorylation of EGFR to the same degree, and following the same time course.

The obtained results strongly suggest that inhibition of EGFR activation is the first (main) step in inhibition of mitogen signaling in DU145 cells, regardless of the kind of ligands (TGF $\alpha$, IGFs or VEGF) and their specific receptors.

\section{DISCUSSION}

Autocrine growth stimulation of DU145 cells by EGF/ TGF $\alpha$ is well documented (Salomon et al., 1995; Seth et al., 1999; Blackledge, 2003). The results of earlier experiments (Ferrer et al., 1999; Gennigens et al., 2006) indicated that DU145 cells showed also overexpression of IGFII and VEGF. These findings, in connection with an increased level of IGFRI and VEGFRs, suggested the participation of IGFRs and VEGFs in autocrine growth regulation of the investigated cells. There was one in vitro study which showed that IGFIR antibodies inhibited DNA synthesis in PC3, but not the DU145 cell lines (Kimura et al., 1996); however, other investigators found that IGFIR antibody prevents proliferation of both the prostate cell lines (Maloney et al., 2003). Although an association may exist between IGFI and prostate cancer, direct causality has not been established (Meinbach \& Lokeshwar, 2006). Another question is the role of VEGFR in autocrine growth regulation of prostate cells. Several investigations indicated that VEGF is mainly the angiogenic and chemotactic factor for prostate cancer cells; however, it may regulate tumor growth in vitro (Jackson et al., 2002).

We have determined (Kisielewska et al., 2008) that blockade of the IGFIR or VEGF2R signaling pathways inhibits autocrine growth and viability of DU145 cells in vitro. Our results indicate that both investigated tyrphostins (AG1024 and SU1498) at concentration $\geq 10 \mu \mathrm{M}$ are able to inhibit completely DU1a 45 autocrine cell growth. These results suggest that the two growth factor receptors (IGFIR, VEGFR2) induce a common signaling route, or that activation of one of the investigated receptors influences the mitogenic pathway of the other. Further experiments have revealed that both the investigated inhibitors increase the percentage of DU145 cells in $G_{0} / G_{1}$ phase of 
cell cycle, indicating that AG1024 and SU1498 arrest cell growth in $G_{0} / G_{1}$ phase, similarly as do known inhibitors of EGFR (Bonaccorsi et al., 2004; Bellezza et al., 2006).

A comparison of the $\mathrm{IC}_{50}$ values for the anti-proliferative and enzyme inhibitory activities (12:1) of AG1024 suggests that the true ligand for IGFIR in the case of DU145 cells is IGFII rather than IGFI, and supports the hypothesis of IGFII/IGFIR autocrine loop in this type of cancer prostate cells (Figueroa et al., 1995). We confirm that DU145 cells do not produce insulin-like growth factor I, and IGFI cannot be an autocrine growth factor for these cells. In contrast, DU145 cells produce a great amount of VEGF (much more than TGF $\alpha$ ) and this protein may be the real autocrine growth factor of the investigated cells. Incubation of DU145 cells with AG1024 and SU1498 indicates a weak (about $25 \%$ of the control) and opposing effect of these tyrphostins on production of TGF $\alpha$, which excludes the possibility that IGFs and VEGF stopped the growth of these cells by inhibition of synthesis or secretion of TGF $\alpha$.

The mitogenic pathways stimulated by growth factors engage several proteins, including Akt (PKB), ERK(1/2), Src and STAT, the activity of which is regulated by phosphorylation/dephosphorylation. The obtained data indicate that all three tyrphostins inhibit intracellular signaling pathways, triggered by EGFR, IGFIR and VEGFR2 receptor, in a similar manner. A comparison of the effect of the investigated tyrphostins points to a similarity in TGF $\alpha$, IGFII and VEGF-stimulated pathway signaling.

Unexpectedly, all the investigated inhibitors used at their respective $\mathrm{IC}_{50}$ concentrations decreased phosphorylation of EGFR to the same extent. These results strongly suggest that activation of EGFR is the first (main) step in initiation of mitogen signaling in DU145 cells, regardless of the kind of ligands (TGF $\alpha$, IGFs or VEGF) and their specific receptors.

The presented results show that autocrine growth of DU145 may be regulated by at least two additional autocrine loops: IGFII/IGFIR and VEGF/VEGFR2, apart from the well-documented TGF $\alpha / E G F R$ loop. Such multifactor regulation of the autocrine growth of the metastatic cancer cell line DU145 may explain the failure of single specific tyrosine kinase inhibitors in the therapy (monotherapy) of prostate cancer (Blackledge, 2003; Pu et al., 2006). A role for the autocrine growth loop involving tyrosine kinases and their receptors in tumor progression has been suggested for a variety of cancers. Identifying biologically and physiologically important autocrine growth events may have important clinical consequences, also for the introduction of new strategies in anticancer therapies.

\section{REFERENCES}

Bellezza I, Bracarda S, Caserta C, Minelli A (2006) Targeting of EGFR tyrosine kinase by ZD1839 ("Iressa") in androgen-responsive prostate cancer in vitro. Mol Genet Metab 88: 114-122.

Bennasroune A, Gardin A, Aunis D, Cremel G, Hubert P (2004) Tyrosine kinase receptors as attractive targets of cancer therapy. Crit Rev Oncol Hematol 50: 23-38.

Blackledge G (2003) Growth factor receptor tyrosine kinase inhibitors; clinical development and potential for prostate cancer therapy. $J$ Urol 170: S77-83; discussion S83.

Bonaccorsi L, Marchiani S, Muratori M, Forti G, Baldi E (2004) Gefitinib ('IRESSA', ZD1839) inhibits EGF-induced invasion in prostate cancer cells by suppressing PI3 K/AKT activation. J Cancer Res Clin Oncol 130: 604-614.

Ferrer FA, Miller LJ, Lindquist R, Kowalczyk P, Laudone VP, Albertsen PC, Kreutzer DL (1999) Expression of vascular endothelial growth factor receptors in human prostate cancer. Urology 54: 567-572.

Figueroa JA, Lee AV, Jackson JG, Yee D (1995) Proliferation of cultured human prostate cancer cells is inhibited by insulin-like growth factor (IGF) binding protein-1: evidence for an IGF-II autocrine growth loop. J Clin Endocrinol Metab 80: 3476-3482.

Gennigens C, Menetrier-Caux C, Droz JP (2006) Insulin-like growth factor (IGF) family and prostate cancer. Crit Rev Oncol Hematol 58: 124-145.

Goustin AS, Leof EB, Shipley GD, Moses HL (1986) Growth factors and cancer. Cancer Res 46: 1015-1029.

Jackson MW, Roberts JS, Heckford SE, Ricciardelli C, Stahl J, Choong C, Horsfall DJ, Tilley WD (2002) A potential autocrine role for vascular endothelial growth factor in prostate cancer. Cancer Res 62: 854-859.

Jimeno A, Hidalgo M (2005) Blockade of epidermal growth factor receptor (EGFR) activity. Crit Rev Oncol Hematol 53: 179-192.

Jones HE, Goddard L, Gee JM, Hiscox S, Rubini M, Barrow D, Knowlden JM, Williams S, Wakeling AE, Nicholson RI (2004) Insulin-like growth factor-I receptor signalling and acquired resistance to gefitinib (ZD1839; Iressa) in human breast and prostate cancer cells. Endocr Relat Cancer 11: 793-814.

Kimura G, Kasuya J, Giannini S, Honda Y, Mohan S, Kawachi M, Akimoto M, Fujita-Yamaguchi Y (1996) Insulin-like growth factor (IGF) system components in human prostatic cancer cell-lines: LNCaP, DU145, and PC-3 cells. Int J Urol 3: 39-46.

Kisielewska J, Ligeza J, Klein A (2008) The effect of tyrosine kinase inhibitors, tyrphostins: AG1024 and SU1498, on autocrine growth of prostate cancer cells (DU145). Folia Histochem Cytobiol 46: 185-191.

Lacal JC (2006) "Changing the course of oncogenesis: The development of tyrosine kinase inhibitors." EJC Suppl. 14-20.

Levitzki A, Gazit A (1995) Tyrosine kinase inhibition: an approach to drug development. Science 267: 1782-178.

Madhusudan S, Ganesan TS (2004) Tyrosine kinase inhibitors in cancer therapy. Clin Biochem 37: 618-635.

Maloney EK, McLaughlin JL, Dagdigian NE, Garrett LM, Connors KM, Zhou XM, Blattler WA, Chittenden T, Singh R (2003) An anti-insulin-like growth factor I receptor antibody that is a potent inhibitor of cancer cell proliferation. Cancer Res 63: 5073-5083.

Marker PC, Donjacour AA, Dahiya R, Cunha GR (2003) Hormonal, cellular, and molecular control of prostatic development. Dev Biol 253: $165-174$.

Meinbach DS, Lokeshwar BL (2006) Insulin-like growth factors and their binding proteins in prostate cancer: cause or consequence? Urol Oncol 24: 294-306.

Montano X, Djamgoz MB (2004) Epidermal growth factor, neurotrophins and the metastatic cascade in prostate cancer. FEBS Lett 571: $1-8$.

Ozen M, Giri D, Ropiquet F, Mansukhani A, Ittmann M (2001) Role of fibroblast growth factor receptor signaling in prostate cancer cell survival. J Natl Cancer Inst 93: 1783-1790.

Pasanen T, Saarela J, Saarikko I, Toivanen T, Tolvanen M, Vihinen M, Wong G (2003) DNA microarray data analysis. Helsinki, CSC - Scientific Computing Ltd.

Pu YS, Hsieh MW, Wang CW, Liu GY, Huang CY, Lin CC, Guan JY, Lin SR, Hour TC (2006) Epidermal growth factor receptor inhibitor (PD168393) potentiates cytotoxic effects of paclitaxel against androgen-independent prostate cancer cells. Biochem Pharmacol 71: $751-760$.

Quackenbush J (2002) Microarray data normalization and transformation. Nat Genet 32 (Suppl): 496-501.

Saeed AI, Sharov V, White J, Li J, Liang W, Bhagabati N, Braisted J, Klapa M, Currier T, Thiagarajan M, Sturn A, Snuffin M, Rezantsev A, Popov D, Ryltsov A, Kostukovich E, Borisovsky I, Liu Z, Vinsavich A, Trush V, Quackenbush J (2003) TM4: a free, open-source system for microarray data management and analysis. Biotecbniques 34: 374-378.

Salomon DS, Brandt R, Ciardiello F, Normanno N (1995) Epidermal growth factor-related peptides and their receptors in human malignancies. Crit Rev Oncol Hematol 19: 183-232.

Seth D, Shaw K, Jazayeri J, Leedman PJ (1999) Complex post-transcriptional regulation of EGF-receptor expression by EGF and TGF-alpha in human prostate cancer cells. Br J Cancer 80: 657-69.

Sgambato A, Camerini A, Faraglia B, Ardito R, Bianchino G, Spada D, Boninsegna A, Valentini V, Cittadini A (2004) Targeted inhibition of the epidermal growth factor receptor-tyrosine kinase by ZD1839 ('Iressa') induces cell-cycle arrest and inhibits proliferation in prostate cancer cells. J Cell Physiol 201: 97-105.

Sigala S, Bodei S, Missale C, Zani D, Simeone C, Cunico SC, Spano PF (2008) Gene expression profile of prostate cancer cell lines: effect of nerve growth factor treatment. Mol Cell Endocrinol 284: 1120.

Sporn MB, Roberts AB (1985) Autocrine growth factors and cancer. Nature 313: 745-147.

Vicentini C, Festuccia C, Gravina GL, Angelucci A, Marronaro A, Bologna M (2003) Prostate cancer cell proliferation is strongly reduced by the epidermal growth factor receptor tyrosine kinase inhibitor ZD1839 in vitro on human cell lines and primary cultures. J Cancer Res Clin Oncol 129: 165-174. 